\title{
6. Campaign Advertising and Communication Strategies in the Election of 2013
}

\author{
Sally Young
}

For 40 years, Australia's major political parties have prioritised television and viewed it as the pre-eminent medium for communicating with voters during an election. As Gough Whitlam's speechwriter, Graham Freudenberg (2000: 122), observed first-hand, the 1969 election was 'the last campaign that wasn't tailored mainly to TV'. From 1972 onwards, the parties have focused both their 'paid media' strategies (commercial advertising) and their 'free media' (media management) activities upon TV (Young 2011: 126-45). But in 2013, with fragmenting media audiences diminishing television's impact and audience reach, the major parties took a multi-faceted approach. While TV ads were still the major component of their communication strategies, these were supplemented by other forms of communication including both digital and oneto-one methods. This was a campaign notable for the parties' use of information gleaned from market research and new methods of detailed data analysis, their reliance upon professionalised campaign operatives and their increased use of targeting and micro-targeting approaches to reach strategically important voters.

\section{Advertising and campaign spending}

In a less than promising start for Labor, planning for the Party's advertising strategy was disrupted when its relationship with its original advertising agent, Mark Collis, broke down around March 2013. Labor then assembled a new team comprising Essential Media Communications (the progressive polling and campaigning group responsible for the Australian Council of Trade Union's 2007 Your Rights at Work campaign) and advertising agent Dee Madigan. In a blaze of publicity, Labor also brought in international expertise in digital media in the form of Obama campaign veterans. These included British social media strategist Matthew McGregor (dubbed 'Obama's digital attack dog') and Tom McMahon, the former executive director of the Democratic National Committee. Reportedly without consulting central campaign headquarters, Kevin Rudd also brought back Neil Lawrence from the Kevin07 campaign to develop the 
slogan 'A New Way' and the accompanying advertisement which suggested an initial 'positive' focus that later gave way to more standard negative campaign techniques.

As befits a conservative party, the Liberal Party stuck with its longstanding inhouse team of market researchers and strategists, Mark Textor and the Crosby Textor group, along with advertising agent Mark Pearson who had worked for the Liberals since the 1996 campaign. And, as befits a party that was widely expected to win, the Liberal advertising campaign played it safe and relied upon traditional challenger messages which highlighted disunity and inconsistency in the government and promoted the need for change.

Campaign spending patterns reveal important information about the campaign priorities and strategies of the parties but, unfortunately, accurately determining election advertising spending is extraordinarily difficult in Australia. Despite the generous public funding provided for Australian election campaigns, political parties are not required to disclose how they spend their funds during federal elections. Other countries - including the United Kingdom-have much stronger disclosure and political finance reporting requirements. In Australia, there is a troubling lack of transparency and accountability by comparison (Young and Tham 2006; Ewing, Rowbottom and Tham 2012). As a result, we have to rely upon estimates of party spending, particularly from commercial agents monitoring advertisement buying in the political domain, known in the industry as 'ad buy monitors'. These estimates can vary significantly.

Before the election, there had been estimates in media outlets that the two major parties would spend \$20-25 million each. There were even estimates during the campaign that they would spend a record amount of up to $\$ 90$ million (e.g. Shanahan 2013). But after the election, in one of the more comprehensive estimates of spending, advertising monitoring group ebiquity suggested the two parties spent a combined total of just under $\$ 11$ million across TV, radio and print with the Liberal Party spending \$6.75 million compared to \$4.04 million for Labor (for the period 5 August to 6 September 2013) (Campaign Brief 2013). In contrast, global measurement company Nielsen reported that the two parties spent a total of $\$ 18.5$ million with at least $\$ 11$ million spent by the Liberals and $\$ 7.5$ million by the ALP throughout the campaign on multiple types of advertising including broadcast, print, out-door and direct mail (Nielsen 2013; Aqx 2013). According to Nielsen, the Liberal Party spent more than $\$ 4$ million in just the last week of the campaign alone compared to Labor's spending of \$1.5 million in that last week.

So, whether the two parties' combined total spending was as low as \$11 million (a figure that a senior campaign strategist for one of the major parties refuted as being far too low) or, more likely, over $\$ 18.5$ million (as reported by Nielsen), 
their overall spending did still seem to be less than anticipated and less than is usual. For the 2010 election, the two parties reportedly spent around $\$ 27$ million (combined) on TV advertising alone, up from around \$24 million in 2004 (Young 2005: 103; see also Young 2004: 41). Estimates of spending in 2013 therefore seem relatively low.

One clear indicator that the major parties did feel they were short of cash in 2013 was their thwarted attempt earlier in the year to increase public funding for campaigns through legislation. That deal would have delivered around \$20 million a year to all parties and elected independents over three years for 'administrative purposes', but it was dropped after a public backlash. The attempt to boost public funding arose because the parties have faced increasingly lean times in terms of private fundraising. Between the 1998 and 2010 elections, the total pool of private donations going to the ALP and the Liberal Party shrank from $\$ 76$ million to $\$ 61$ million (Tham and Anderson 2013). But it may also be that, with the result seemingly a foregone conclusion, neither party was willing to spend up big or go into debt. This was especially true for Labor which, as the clear underdog, probably had fewer private donations and perhaps judged that it was wiser to conserve some funds for a future campaign with better prospects.

Although the campaign advertising spending estimates provided by different monitoring companies varied, they did contain some similar conclusions. Of the two major parties, the Liberals outspent Labor during the campaign by at least double - or even by four to one according to some reports - in the crucial final few days before the electronic blackout (Campaign Brief 2013; Jackson 2013; Nielsen 2013). Liberal Party resources seem to have been especially focused upon the last two weeks of the campaign.

Another important point of agreement was the evidence that the two major parties had new competition during the 2013 election. According to ebiquity, billionaire Clive Palmer's Palmer United Party almost rivalled Labor's total spending and, on both the Nielsen and ebiquity figures, Palmer definitely outspent Labor during the last week (Campaign Brief 2013; Nielsen 2013). But, again demonstrating the confusion and misinformation that inadequate disclosure provisions in Australia cause, while Palmer reportedly spent \$3.02 million on advertising during the election (Campaign Brief 2013), others suggested he spent 'about $\$ 12$ million' (Hurst 2013). Palmer himself suggested his party spent between \$10-12 million during the campaign (AAP 2013; for further discussion and analysis of Clive Palmer's party in the 2013 election, see Chapter 17 by Tom King).

Both the ebiquity and Nielsen reports on spending show that the other major new player in 2013 was a third party interest group rather than a political party. The Australian Salary Packaging Association reportedly spent over \$1.4 million 
on advertising during the election to lobby against Labor's proposed changes to the fringe benefits tax on car leases (Nielsen 2013; Campaign Brief 2013). Close behind in spending was the pro-mining Australian Petroleum Production and Exploration Association, the leading lobby group for the oil and gas industry, which reportedly spent $\$ 1.2$ million on ads during the election (Campaign Brief 2013). By comparison, the Greens were reported to have spent about half that of the Australian Salary Packaging Association (Campaign Brief 2013). The Greens focused particularly on the seat of Melbourne in what may have been the biggest expenditure in a single seat.

The Australian Chamber of Commerce and Industry also launched an advertising campaign to promote issues important to small business called 'Small Business Too Big To Ignore'. Other older (non-party) advertisers included the ACTU and GetUp! which both spent over \$500,000 during the 2013 campaign (Campaign Brief 2013). The ACTU started advertising in June 2013 under the banner 'Australian Unions. Join. For a Better Life'. The ACTU argued this was about issues broader than just the election but others viewed the advertising as designed to support Labor's re-election. Combined spending by major unions-including the ACTU but also the Australian Education Union, the National Union of Workers, the Construction, Forestry, Mining and Energy Union, and the National Tertiary Education Union - exceeded \$1.5 million (Campaign Brief 2013).

The high spending in 2013 by third party groups trying to influence election outcomes and party policy is the continuation of a tradition in recent years in Australia which has seen advertising become a dominant method of political discourse. This is not confined to elections. Businesses ran various expensive campaigns against Labor government policy between 2007 and 2010 including campaigns against the mining tax, carbon pricing, cigarette plain packaging and gambling reforms. Nor is the advertising confined to parties and interest groups.

Governments have also run expensive campaigns - at taxpayer expense - to either promote or defend themselves and their policies. This trend accelerated in the 2000s with the Howard government's advertising on the Goods and Services Tax (Unchain My Heart) and later its WorkChoices policy (Young 2007), and continued under the Rudd and Gillard governments so that it is now impossible to examine (political) election advertising without also considering pre-election, and even caretaker period, government advertising.

Indeed, one of the controversies that erupted during the 2013 election was the Labor government's use of government advertising during the caretaker election period. The Labor government continued an advertising campaign about its new asylum seeker deal with Papua New Guinea that included full-page newspaper ads stating, 'If you come here by boat without a visa-YOU WON'T BE SETTLED 
IN AUSTRALIA' and warning that asylum seekers were 'buying a ticket for another country'. These ads ran heavily in domestic newspapers, radio and TV from July and into the campaign proper. This provoked controversy, as it had during previous elections, about caretaker conventions and the potential misuse of government advertising for partisan purposes just before, or even during, an election. ${ }^{1}$ During the election period in 2004, for example, the Howard government ran 'Help protect Australia from terrorism' ads on TV, radio and in newspapers that Labor at the time criticised as unreasonable and as creating a potential political advantage during the election (Young 2005: 104).

This is an extension of another familiar pattern since the 2000s; namely that of sudden surges in incumbent spending on government advertising in the lead up to an election (Grant 2003-04). The Howard government, in its final year, reportedly spent $\$ 254$ million (Lewis 2013b). In 2013, Labor government advertising spending surged in the three months before the election with advertising campaigns on asylum seeker policy, the National Broadband Network (NBN), the Gonski education reforms, household assistance and the National Disability Insurance Scheme (NDIS). Estimates suggested that spending on federal government advertising surged by 50 per cent in April 2013 alone, including over $\$ 50$ million spent in the four months before the election (West Australian 2013; Coyne 2013; Priest and Anderson 2013).

Aside from the pre-election and caretaker period government advertising campaigns, there were two other interesting political advertising controversies in 2013. After the electronic advertising blackout was enforced at midnight on the Wednesday before polling day, viewers continued to see Palmer-themed commercials for the Palmer Coolum Resort. Palmer spokespeople argued these were not political and therefore did not breach the blackout rules (Hurst 2013). Raising some very different issues (less about rule enforcement than about media censorship), a GetUp! advertisement critical of Rupert Murdoch and News Corporation's anti-Labor campaign in its newspapers (especially the Daily Telegraph and the Courier-Mail) was dropped by Channel Nine even though it was approved for broadcast by Free TV Australia. Channels Seven and Ten also refused to run the ads.

\footnotetext{
1 Liberal Senator George Brandis said the ads were 'nothing but political advertisements designed to promote the policies and the propaganda of the Labor Party' (Owens 2013). Tony Abbott called it a 'gross misuse' of public funds (Lewis 2013a). Other critics also suggested the ads seemed designed to reach voters in Australia rather than people overseas contemplating a boat voyage to Australia. Independent Senator Nick Xenophon also complained that Labor was breaching caretaker conventions. The Auditor-General, Ian McPhee, wrote back to say that the caretaker conventions gave the Government latitude regarding advertising campaigns, and noted in any case that the conventions are not legally binding (McPhee 2013).
} 


\section{'Old' media, technology and communications: TV, radio, print, direct mail, door-knocking and phone banks}

Television advertisements still constituted the biggest single expenditure for the major parties and were the central focus of their advertising and communications plans, as has been the case since the 1970s. However, a range of newer methods of communications were also put to use and traditional methods of face-toface communication, print and telephones also experienced something of a resurgence as the parties took a mixed approach to their communications.

The Liberal Party's use of printed material to promote its Real Solutions Plan was a key to its communications strategy (as Nicholas Reece explains in Chapter 7). Distribution of five million copies of what is, for political mail, a very dense booklet, was a significant investment in print. The Liberals appear to have spent nearly three times as much on direct mail as Labor did (Aqx 2013). On the Labor side, greater investment was made in metropolitan radio advertising and on using American-style telephone banks for cold calling. Labor made over one million calls to voters in marginal seats using volunteers as well as MPs and candidates (ALP 2013). This was reportedly a more than ten-fold increase on the number of people Labor called in 2010 (Kenny 2013). Aside from 'live' phone calls, 'robocalls' were also a feature of the 2013 campaign, although they are used much less extensively in Australia than in the United States (in Australia, the 2004 election was reported to represent the peak of robocalling). 'Live' calls are considered far more effective. Unlike commercial entities, political parties are exempt from respecting the requirements of the Do Not Call register which allows people to be put on a list of those who do not wish to receive marketing phone calls.

In 2013, the parties made use of a variety of techniques because, as audiences fragment, so too do the communications strategies of the parties and different media are used for different purposes. For example, although it receives vastly less advertising spending than TV, radio is still a useful medium because, as infrastructure fails to keep up with population growth, more people spend more time in their cars during long commutes and more regular traffic jams. Door-knocking is also an important part of on-the-ground campaigns as a way of achieving the sort of one-on-one interaction that Labor's phone calls were aiming for (Mills 2014: 201-2). Among the more publicised examples of this was the Coalition candidate Michael Feneley in Kingsford Smith who reportedly door-knocked 18,000 houses and Michelle Rowland's volunteers who reportedly door-knocked 50,000 houses in Greenway. 
Even the return to 'traditional' campaigning methods such as mail and doorknocking seen in 2013 were, unlike bygone eras, underpinned by sophisticated databases and the use of increasingly refined data mining on voters and data analysis techniques to target particular voters or groups.

\section{‘New' communications: Online, digital and social media}

Data has long been important in Australian election campaigns (van Onselen and Errington 2004) and the parties have built up extensive databases on voters since the 1980s. But the degree of sophistication involved in collecting and using that data is advancing rapidly. In 2013, Labor employed individuals and firms specialising in the use of algorithms that can sort voters into useful categories (including predictions of their voting intentions) to help the Party target campaign resources toward the right electorates, suburbs and even streets (O'Malley and Johnson 2013). Such individuals and techniques are especially associated with US campaigns, and the use of 'big data' to 'micro-target voters' was discussed by Labor's (and Obama's) digital strategist Matthew McGregor in a 2012 article (Faust and McGregor 2012).

The 2013 campaign also saw continued experimentation with digital ads, including ads on social media sites, pop-up ads on online news sites andespecially after the Wednesday midnight blackout which halts political advertising on TV and radio - ads on YouTube and Facebook. Labor designed an elaborate spoof campaign for a fake product that it launched through a central website, Facebook marketing and YouTube videos. The fake product was 'Abbott's Internet' to be 'sold' on the streets of Prague, New York, Singapore and Bucharest. The punchline was that 'Abbott's Internet' was slow, wouldn't be delivered until 2019 and by then would already be out of date. Labor also fed the advertisement for the fake internet provider through its alternative social media presence which had minimal Labor branding, and which was used for more off-beat (and often more negative) messages.

After the election, both major parties were quick to claim digital media superiority. Labor claimed to have harnessed over 230,000 email addresses (compared to only 30,000 in 2010), sent over three million emails to supporters and raised funds of over $\$ 700,000$ through nearly 10,000 online donors (ALP 2013). Meanwhile, the Liberal Party claimed after the election to have comprehensively outperformed Labor in social media, pointing to its website visitor numbers, Facebook page 'likes', the reach of its targeted Sharing app, growth in its leaders' Twitter followers and views on its YouTube channel as evidence (Loughnane 2013; see also Chapter 5 by Peter John Chen). 
As anyone who signed up to a major party's email list can attest, the parties sent frequent email messages during the campaign. Mostly these were soliciting donations but many also communicated specific campaign messages. Even these emails were part of a sophisticated technological operation behind the scenes. The computers that sent the emails were also monitoring responses and learning from them in order to fine-tune the messages in each email. This meant that, after months of testing, emails could be directed very specifically and with carefully designed scripts. These processes continued to evolve throughout the campaign.

\section{Advertising priorities and messages}

The strength and consistency of the Coalition's lead prior to the election meant the Liberal Party's ads could focus on reinforcing pre-existing perceptions. The conservatives could also run predominantly as a buoyant challenger and fated victor in the mould of the Whitlam Labor 'It's Time' campaign in 1972. One sign of this was the way the Liberals focused on positive ads. Federal Director Brian Loughnane (2013) argued after the election that more than 70 per cent of their advertising was positive and that figure was supported by independent research by ebiquity. Conversely - and with a glaring inconsistency with Rudd's 'new way' positive message at the beginning of the campaign - three-quarters of Labor's advertising was negative (Campaign Brief 2013).

Of all the election ads running in 2013, it is telling that the single most broadcast TV advertisement of the campaign appears to have been Palmer's 'Revolution' advertisement (Campaign Brief 2013). It showed Palmer talking to camera saying, 'We want to give you money back. $\$ 2,500 \ldots$ off your tax bill so that you can spend the money. You can decide what your family needs. Not the government'; and promising 'more jobs' and 'more growth'. Palmer's extraordinary level of advertising expenditure for a minor party was widely credited with building crucial name recognition and his party's unexpected success viewed as a demonstration of the influence of both money and advertising in Australian politics.

Yet, at the same time as a billionaire candidate was using his personal resources to underwrite the biggest minor party campaign in Australian political history, at the other end of the spectrum, Cathy McGowan was running as an independent in Indi and using 'crowd funding' pitches via Chip In and social media to raise money for advertising and campaigning. McGowan (2013) reported raising $\$ 117,000$ from over 1,000 different donors (see Jennifer Curtin and Brian Costar's analysis in Chapter 16). 
For the Coalition and Labor, their most shown ads (which they presumably, therefore, had judged to be their most effective) were the Liberal Party's 'Captain Chaos' and 'Our Plan' ads and, for Labor, its 'You Lose' ad. The Liberal's 'Captain Chaos' advertisement targeted Kevin Rudd's handling of financial management and asylum seeker policies as a 'Ruddy mess'. It showed multiple images of Rudd's face on screen including stills from the infamous leaked out-takes of him as foreign minister swearing in frustration. The 'Captain Chaos' advertisement ended with the line 'All this chaos in just 31 days. Imagine three more years of Labor failure'. The Liberal's 'Our Plan' advertisement referenced the Party's published booklet and showed Tony Abbott promising that:

Our Plan will deliver two million more jobs over the next decade and better services for you and your family ... lower taxes and lower debt and stronger borders where the boats are stopped.

Labor's most shown advertisement was 'If Abbott wins, you lose'. It showed concerned-looking ordinary Australians standing in spotlights being relegated to the dark when the lights are successively turned out on them as the serioussounding voiceover makes claims about how Abbott's plans will affect people. ${ }^{2}$ Light is a classic political metaphor. Indeed, the Liberal's 1975 campaign slogan was 'Turn on the lights' after what they characterised as the 'three dark years' of Labor's Whitlam Government (Penniman 1977: 204-8; Young 2004: 120-2). But the notion of families being struck down is also common in political advertising. In 1993, the Liberal Party made a memorable and controversial advertisement that showed ordinary people as targets, being viewed through the cross hairs of a gun and struck down by Labor's 'mismanagement' and failure to stop high unemployment rates (Young 2004: 270). Labor had its own series of ads in 1998 showing family photos with the faces crossed out by a black marker as the voiceover explained how the Howard Government had adversely affected them.

\section{Conclusion}

Both Brian Loughnane and George Wright identified the 2013 campaign as different to its predecessors. Loughnane (2013) argued the Liberal's success showed that negativity is not the only way to campaign. But Rudd's adviser, Bruce Hawker (2013), countered that the Liberals did not need to run a negative

2 The Conversation 'fact-checked' this advertisement as part of its series of fact-checks. The ABC, Fairfax and Peter Fray's PolitiFact Australia also ran fact checks during the campaign and all four outfits concentrated mostly on fact-checking statements and claims rather than political ads. These 'fact-checks' were a new part of the media landscape of Australian elections but have been widely used in the US where there are also specific 'Ad Watches'. American broadcasters began in 1992 to broadcast 'Ad Watches' that critique political ads and interrogate their claims (Hall Jamieson and Cappella 1997). These ads are broadcast on the same medium as the original ads, giving them much broader reach. We have yet to see these on commercial TV in Australia. 
campaign in 2013 because the Murdoch press ran it for them (see Wayne Errington's chapter). In terms of campaign methods, Wright (2013) argued that the 2013 campaigns were a further step into a third generation of campaigning based not on mass advertising alone or demographic targeting but on 'direct, and individual, one-on-one conversation and voter engagement, and the microtargeting of information and messages to individuals'. For campaign observers, including political scientists and journalists, this poses a challenge because there is an increasing need to see things that are beyond our immediate sight and that are difficult to access or evaluate using traditional methods of analysis.

To get a full picture of how the parties communicate with voters now requires examining not only modes of communication which are highly visible or easily accessible - such as TV ads, list emails or Facebook posts - but also some new methods of gaining access to, and making sense of, the vast array of individualised messages that the parties communicate through letters, phone calls and conversations with hundreds of thousands of individual voters. We must be able to analyse both the macro and micro campaigns that occur throughout Australia during a campaign. At the macro level, we especially need a full picture of campaign spending. At present, the lack of clear information about spending is impairing our understanding and the need for better disclosure is becoming more pressing as wealthy individuals, corporate interests and other third party groups become more substantial and overt players in elections.

\section{References}

Australian Associated Press (AAP). 2013. 'Clive Palmer says questions about his spending are a political witch-hunt'. The Australian, 7 November: <www. theaustralian.com.au/national-affairs/clive-palmer-says-questions-abouthis-spending-are-a-political-witch-hunt/story-fn59niix-1226754711424>.

Australian Labor Party (ALP). 2013. 'The million person campaign: A report to members'. Emailed report sent by George Wright to ALP email list recipients, 12 September.

Aqx. 2013. 'Standard report'. ABC News, viewed 15 January 2014: <www. abc.net.au/news/2013-09-20/ad-spending-claims-pure-campaign$\operatorname{spin} / 4966426>$.

Campaign Brief. 2013. 'Liberal Party beats Labor Party in campaign advertising stakes and at the polls - ebiquity'. 9 September, viewed 15 January 2014: $<$ www.campaignbrief.com/2013/09/the-liberal-party-beats-labor.html >. 
Coyne, Brendan. 2013. 'Government spending pushes ad market to record July'. Ad News, 15 August.

Ewing, Keith, Rowbottom, Jacob and Tham, Joo-Cheong. 2011. The Funding of Political Parties: Where Now? New York: Routledge.

Faust, Patrick and McGregor, Matthew. 2012. '2012 from an international perspective'. Huffington Post, 10 December, viewed 15 January 2014: <www. huffingtonpost.com/patrick-faust/2012-from-an-internationa_b_2272801. html>.

Freudenberg, Graham. 2000. Recorded interview with Graham Freudenberg AM, Interviewer: John Farquharson. Oral History Section, Canberra, National Library of Australia (CTRC 3994).

Grant, Richard. 2003-04. Research note no.62 2003-04: Federal government advertising. Canberra: Parliamentary Library, Parliament of Australia.

Hall Jamieson, Kathleen and Cappella, Joseph N. 1997. 'Setting the record straight: Do ad watches help or hurt?' The Harvard International Journal of Press/Politics 2(1): 13-22.

Hawker, Bruce. 2013. The Rudd Rebellion: The Campaign to Save Labor. Melbourne: Melbourne University Publishing.

Hurst, Daniel. 2013. 'Palmer party denies resort ads breached TV blackout'. The Sydney Morning Herald, 11 September.

Jackson, Sally. 2013. 'Big-spending Libs left Labor for dead on advertising'. The Australian, 9 September: 28.

Kenny, Mark. 2013. 'Big call: Labor hits the phone'. The Sydney Morning Herald, 27 August.

Lewis, Steve. 2013a. 'Abbott sinks boot into Labor over litz of refugee boat ads'. Courier-Mail, 30 July: 2.

Lewis, Steve. 2013b. 'Anger at Labor's ad spend of \$65m'. Cairns Post, 22 July: 6.

Loughnane, Brian. 2013. 'The 2013 Federal Election: Address to the National Press Club'. Canberra, 23 October.

Mills, Stephen. 2014. The Professionals: Strategy, Money and the Rise of the Political Campaigner in Australia. Melbourne: Black Inc.

McGowan, Cathy. 2013. 'The story', Cathy McGowan [official website], viewed 15 January 2014: <www.cathymcgowan.com.au/the_story>. 
McPhee, Ian. 2013. 'Letter to Senator Nick Xenophon'. 14 August, viewed 15 January 2014: <www.anao.gov.au/Whats-New/ANAO-News/ /media/6FC3 0264813E4B64BE1E5C86CC206940.PDF>.

Nielsen. 2013. 'Press release: Australians jump online for last minute election news'. 21 October: <www.nielsen.com/content/dam/corporate/au/en/ press/2013/nielsen-media-release-online-results-for-September-21.10.13. pdf $>$.

O'Malley, Nick and Johnson, Chris. 2013. 'How Barack Obama is changing the face of Australian political campaigns'. The Sydney Morning Herald, 4 August.

Owens, Jared. 2013. 'New leg of "unlawful" boat ads launched'. The Australian, 10 August: 9.

Penniman, Howard R. 1977. Australia at the Polls: The National Elections of 1975. Washington, D.C.: American Institute for Public Policy Research.

Priest, Marcus and Anderson, Fleur. 2013. 'Handouts galore as $\$ 725 \mathrm{~m}$ set aside'. Australian Financial Review, 16 May: 9.

Shanahan, Dennis. 2013. 'Libs call off TV blitz to focus spending on final stretch'. The Australian, 22 August: 6.

Tham, Joo-Cheong and Anderson, Malcolm. 2013. Raw data based upon political party returns to the AEC and collated by Tham and Anderson, provided to the author in correspondence, 26 November.

van Onselen, Peter and Errington, Wayne. 2004. 'Electoral databases: Big brother or democracy unbound?' Australian Journal of Political Science 39(2): 349-66.

West Australian. 2013. 'Election ads to top \$70m'. The West Australian, 24 May: 2.

Wright, George. 2013. 'Address to the National Press Club'. Canberra, 29 October, viewed 15 January 2014: <d3n8a8pro7vhmx.cloudfront.net/ australianlaborparty/pages/1890/attachments/original/1383017072/George_ Wright_Address_to_NPC_Transcript.pdf $>$.

Young, Sally. 2004. The Persuaders: Inside the Hidden Machine of Political Advertising. Melbourne: Pluto Press.

Young, Sally. 2005. 'Political advertising: Hey big spender!' In Marian Simms and John Warhurst (eds), Mortgage Nation: The 2004 Australian Election. Perth: API Network. 
6. Campaign Advertising and Communication Strategies in the Election of 2013

Young, Sally. 2007. 'A history of government advertising in Australia'. In Sally Young (ed.), Government Communication in Australia. Melbourne: Cambridge University Press.

Young, Sally. 2011. How Australia Decides: Election Reporting and the Media. Melbourne: Cambridge University Press.

Young, Sally and Tham, Joo-Cheong. 2006. Political Finance in Australia: A Skewed and Secret System. Canberra: Democratic Audit of Australia, The Australian National University. 
This text taken from Abbott's Gambit: The 2013 Australian Federal Election, edited by Carol Johnson and John Wanna, published 2015 by ANU Press, The Australian National University, Canberra, Australia. 